JAZYKOVEDNÝ ČASOPIS, 2015, roč. 66, č. 1

\title{
SPOJKA KÝM V SÉMANTICKÝCH A KOMUNIKAČNÝCH SÚVISLOSTIACH*
}

\author{
JANA SOKOLOVÁ \\ Katedra rusistiky Filozofickej fakulty Univerzity Konštantína Filozofa v Nitre
}

\begin{abstract}
SOKOLOVÁ, Jana: Conjunction kým ['while'] in semantic and communicative contexts. Journal of Linguistics, 2015, Vol. 66, No 1, pp. 17 - 40.
\end{abstract}

\begin{abstract}
The study focuses on the communication-oriented analysis and interpretation of semantic and communicative (illocutive) functions of the Slovak conjunction kým ['while']. Research is based on the text material of the Slovak National Corpus containing synchronic dynamics of the sentence in which the conjunction kým ['while'] expresses temporal and/or contrastive meanings. Kým ['while'] is understood as a poly-semantic and poly-functional word which forms relations of limitative, successive, simultaneous and contrastive-simultaneous coincidence between an independent clause $(\mathrm{P})$ and a whileclause (Q). Regarding the semantic functions of the conjunction, the study also discusses the function of temporal and pragmatic collocations, and complementary and competitive use of synonymous conjunctions. It verifies the connections between the actual dispositions of the conjunction kým ['while'] and a dialogic or narrative interpretation, the choice of perspective and the sentence order. A part of the study presents the use of the conjunction kým ['while'] in the communicative functions of assertion, direction, interrogation, satisfaction, commission and admonition. It demonstrates the dominance of illocutions which are based on the negative life experience of a speaker.
\end{abstract}

Key words: semantics, conjunction kým ['while'], perspective, communicative function, interpretation

\section{VÝCHODISKÁ A POJMY}

Spojke kým (operátoru - v koncepcii novej slovenskej morfológie Juraja Dolníka, 2005) sústredenú pozornost' venovali Ján Oravec (1971), Adriana Ferenčíková (1986), Ján Horecký (1997), Martina Bodnárová (2009), Pavol Žigo (2010), Виктор С. Храковский (2005), ktorí v intenciách syntaktickej sémantiky kládli dôraz na spojitost' spojky kým s gramatickou kategóriou času, vidu a rodu (diatézou) a možnosti vyjadrenia súčasnosti, predčasnosti a následnosti. Funkciu ruskej spojky пока $\mathrm{v}$ kontexte negácie formulovala Елена В. Падучева (2014).

Vychádzajúc $\mathrm{z}$ dokladov $\mathrm{z}$ textov Slovenského národného korpusu (prim-6.1.20-public-vyv) sa $v$ tejto štúdii zameriavame na (a) opätovné posúdenie sémantických funkcií spojky kým; (b) úlohu temporálnych a pragmatických kolokátov v jej okolí; (c) komplementárne a konkurenčné používanie synonymických spojok;

* Štúdia vznikla v rámci riešenia grantového projektu VEGA 1/0243/15 Text a textová lingvistika $v$ interdisciplinárnych a intermediálnych súvislostiach. 
(d) verifikovanie komunikačných okolností fungovania spojky kým a jej uplatnenie v komunikačných (ilokučných) funkciách.

Ako vyplýva zo statusu konjunkcií, spojka $\boldsymbol{k y ́ m}$ má predovšetkým mereologickú funkciu - do jedného celku spája spravidla dve propozície s rôznym stupňom sémantickej a gramatickej závislosti. Patrí k tým lexikálno-gramatickým prostriedkom, pomocou ktorých sa vyjadruje zmena, a to jednak v rámci (1) tzv. pomerných, resp. relatívnych temporálnych vzt'ahov a jednak (2) kontrastívnych alebo nekontrastívnych vzt'ahov (adverzatívnych $\mathrm{v}$ širokom zmysle slova). Ak sa zmena dotýka syntakticky nadradenej vety, prejavuje sa ako: a) zužovanie platnosti významu syntakticky nadradenej vety: Kým bude starká v poriadku, budú v poriadku i oni; b) kvalifikácia platnosti jej významu: Kým bol stav bezgólový, všetko bolo otvorené; c) kvantifikácia významovej platnosti syntakticky nadradenej vety: Trvalo dlho, kým sa pobalili; d) určovanie okolností deja vyjadreného syntakticky nadradenou vetou: Kým bude záujem o sneh, vleky budú v prevádzke; e) vymedzovanie sémantických entít, na ktoré sa vzt'ahuje dej vyjadrený syntakticky nadradenou vetou: Kým bude preč, autobus môže odíst'; f) intenzifikácia platnosti významu syntakticky nadradenej vety: Trpeli sme a budeme trpiet', kým len budeme žit' (porov. sémantické determinatívne vzt'ahy, ktoré vymedzil J. Kačala, 1998, s. 128).

V rámci súvetia spojka kým si sémanticky podriad’uje tak nadradenú vetu $\mathbf{P}$, ako aj podradenú vetu $\mathbf{Q}$, porov. $\mathbf{P} \leftarrow \boldsymbol{k} \boldsymbol{y} \boldsymbol{m} \rightarrow \mathbf{Q}$. Situáciu, ktorú vyjadruje $\mathbf{P}$, označíme $\mathbf{S}_{1}$, situáciu vyjadrenú vedl'ajšou vetou $\mathrm{Q}$ označíme $\mathbf{S}_{2}$. Teoreticky vznikajú dve možnosti ich syntaktickej realizácie: (1) $\mathrm{S}_{1}$, kým $\mathrm{S}_{2}$; (2) Kým $\mathrm{S}_{2}, \mathrm{~S}_{1}$. Rozloženie situácií (vetosled) ovplyvňuje aktuálne členenie. Prototypickým vetosledom je $\mathrm{P}$, kým $\mathrm{Q}$, v ktorom $\mathrm{S}_{2}$ je rémou, a teda klúčcovou situáciou. Vetosled Kým Q, P je výsledkom aktualizácie $\mathrm{S}_{2}$ a súvisí s jej vytýčením do protikladu (porov. Mluvnice češtiny 3, 1987, s. 598 - 599). Obe rozloženia reflektujú výber perspektívy, ktorá presuponuje rôzne kognitívne predstavy analogických situácií, má rôznu štruktúru (štruktúra perspektívy sa prejavuje v sémantickej interpretácii syntaktických rozdielov) a nevylučuje existenciu akoby centra perspektívy (Борщев - Парти, 2008, s. 146 - 148). Výber perspektívy sa tiež prejavuje vo vol'be slovesného rodu, ktorý je kategoriálnym prostriedkom, dávajúcim hovoriacemu možnost' vyjadrit' jeden a ten istý obsah z rôzneho hl'adiska (Ondrejovič, 1989, s. 81).

Koncept situácie ponímame $\mathrm{v}$ intenciách ruskej lingvistickej tradície ${ }^{1}$, a to jednak ako kognitívnu predstavu štruktúry perspektívy a jednak ako spôsob jej interpretácie. Spája sa s ňou klasifikácia slovies a rozlišovanie deja, procesu, činnosti, stavu, udalosti (porov. Daneš, 1985; Апресян, 2003; Падучева, 2009). Pri dejoch a procesoch je čas nezávisle premennou veličinou. Označujú plynulé dianie, plynulý priebeh a tým zároveň naznačujú možnost' rozkladu, rozkúskovania. $\mathrm{K}$ dištinktívnym vlastnostiam topológie dejov patrí: usporiadanost', spojitost', ohraničenost' (tempo-

${ }^{1}$ Porov. najmä Апресян, Ю. Д. (2003), Храковский, В. С. (2005), Бондарко, А. В. (2005), Падучева, Е. В. (1996, 1986, 2009, 2014). 
rálna, aspektuálna) a rezultatívnost' (Sokolová - Žigo, 2014); statické a substancialistické ponímanie procesu ho charakterizuje ako prechod z jedného stavu do druhého, teda ako systém, jednota stavov (Filkorn, 1998, s. 249). Pri činnostiach a stavoch je čas závisle premennou veličinou. Činnosti sú fyzické, mentálne a rečové aktivity, ktoré sú niekým vykonávané, majú vlastnost' 'kontrolovatel'nosti' (Булыгина, 1982); stavy sú rozpoloženia niekoho, niečoho, majú vlastnosti zmien, prechodov. Udalost' sa vymedzuje ako situácia, lokalizovaná v čase a priestore, ako smerovanie deja k nejakému ciel'u, dosiahnutie ciel’a (v imperfektívnych slovesách napr. chýba implikácia o dosiahnutí/nedosiahnutí ciel'a; vyjadrujú len smerovanie $\mathrm{k}$ jeho dosiahnutiu). S konceptom situácie súvisí aj koncept faktu ( $\mathrm{v}$ jeho informačnom zmysle), ktorý je jednotkou mentálneho uchopenia, je to „niečo overené, objektívne jestvujúce“" (Slovník súčasného slovenského jazyka, 2006 - d’alej SSSJ); fakt je ,stav veci a všeobecne niečo, čo je tu a teraz“ (Filkorn, 1998, s. 291). Vo filozofickom uchopení fakt je entita zodpovedajúca pravdivým výrokom (analytickým aj empirickým); stav veci je to, o čo opierame správnost', oprávnenost' svojho myslenia, rozhodovania, konania a čo je ponímané ako prirodzené, „normálne“. Preto substitúcia mladí $\rightarrow$ starí v súvetí Kým sme mladí ("starí), všetko sa nám zdá krajšie (Krátky slovník slovenského jazyka, 2003 - d’alej KSSJ) napriek svojej gramatickej správnosti odporuje prirodzenému stavu veci a pragmaticky je anomálna.

Súvetia so spojkou kým sú uvádzané v dvoch režimoch interpretácie (termín režim interpretácie zaviedla Е. В. Падучева, 1986) - bud' v dialogickom (rečovom), alebo naratívnom. $\mathrm{V}$ dialogickom režime sa presadzuje perspektíva hovoriaceho, $\mathrm{v}$ naratívnom režime sa uplatňuje perspektíva pozorovatel'a. Výber perspektívy v gramatike súvisí s výberom diatézy (hoci priama závislost' spojky kým od diatézy sa nepotvrdila), modu, času a vidu. Pre sémantiku súvetí so spojkou kým má vid zásadný význam. Všeobecný význam dokonavého vidu ponímame v súlade so slovenskou lingvistickou tradíciou (porov. E. Pauliny, M. Sokolová, A. Jarošová) ako ohraničené trvanie deja (terminatívnost', предельное действие). Е. В. Падучева (1996, s. 24) v súvislosti s dokonavým vidom upozorňuje na situáciu zmeny, porov. ,[совершенный вид] всегда описывает ситуацию изменения, то есть предполагает момент, когда некоторое положение вещей не имело места, и момент, когда имеет (или наоборот)“. Imperfektív v slovenčine aj ruštine opisuje situáciu v jej časovom priebehu, t. j. „как проходящую через ряд последовательных временных фаз“ (ibid.).

Spojku kým ponímame v duchu Moskovskej sémantickej školy ako polysémantické a polyfunkčné slovo majúce vzájomne prepojené a hierarchicky usporiadané významy.

\section{SÉMANTICKÉ FUNKCIE SPOJKY KÝM}

Spojka $\boldsymbol{k y ́ m}$ usúvztažňuje dve rôzne situácie, ktoré sú temporálne synchronizované, a to bud' nekontrastívne, alebo kontrastívne. Synchronizátorom je hovoriaci 
alebo pozorovatel'. V primárne nekontrastívnom usporiadaní je obsah v $\mathrm{P}$ obmedzovaný platnost'ou obsahu v Q a v slovenčine sa realizuje ako (a) ohraničenost' trvania dejov; (b) následnost' trvania dejov; (c) súbežnost' trvania dejov, pričom vo všetkých významoch sa uchováva odtienok kontrastu. V kontrastívnom usporiadaní sú v slovenčine vety s intenciou kontrafaktuálnej zmeny, ktorá naznačuje, že fakty v Q sú z hladiska bežnej skúsenosti a očakávania v rozpore s faktami v P.

To znamená, že spojka $\boldsymbol{k y ́} \boldsymbol{m}$ má v slovenčine štyri významy, vyplývajúce z inherentnej temporálnej perspektívy:

$\boldsymbol{k y ́}^{\boldsymbol{I}}$ : 'P sa odôvodnene uskutočnilo / uskutoční do časového intervalu Q; hovoriaci považuje $\mathrm{P}$ za dostatočné pre uskutočnenie Q'; fakultatívna negácia $\mathrm{v}$ rámci $\mathrm{Q}$; trvanie $\mathrm{P}$ je ohraničené $\mathrm{Q}$;

$\boldsymbol{k y}_{\boldsymbol{y}} \boldsymbol{m}^{2}$ : 'P sa ukončilo pred časovým intervalom Q; hovoriaci považuje čas intervalu Q za možný pre uskutočnenie P'; trvanie $\mathrm{P}$ je ukončené;

$\boldsymbol{k y}_{\boldsymbol{y}} \boldsymbol{m}^{3}$ : 'v časovom intervale Q sa uskutočnilo / uskutočňuje / uskutoční P; hovoriaci považuje $\mathrm{P}$ a $\mathrm{Q}$ za súbežné'; trvanie $\mathrm{P}$ je limitované trvaním $\mathrm{Q}$;

$\boldsymbol{k y ́}^{4} \boldsymbol{m}^{4}$ : 'P a Q sa uskutočnili / uskutočňujú v rovnakom časovom intervale; hovoriaci považuje fakty v $\mathrm{P}$ a $\mathrm{Q}$ za protikladné'.

2.1 Spojka $\boldsymbol{k y ́}^{\boldsymbol{I}}$ spája situáciu $\mathrm{S}_{1}$ a $\mathrm{S}_{2}$, ktorá vyjadruje dôvody ukončenia deja, činnosti, procesu, udalosti, stavu trvajúceho do istého času: „P dovtedy, kým Q“. To znamená, že zjednocuje význam času s významom podmienky (túto možnost' v sémantike spojky kým uvádza aj J. Horecký, 1997). Vyjadruje akoby koncový limit trvania nejakého deja, činnosti, procesu, udalosti, stavu (konečnej stanice; porov. Ferenčíková, 1986), ktoré sú ukončené bud' z objektívnych, alebo subjektívnych dôvodov. Ideu koncového časového limitu nadradenej vety podporuje aj možnost' použit' v nej príslovky dovtedy, dotial', porov. Dovtedy sa chodí s krčahom po vodu, kým sa nerozbije. Vzt’ah medzi P a Q nie je čisto časový, Q je príčinou prerušenia deja, činnosti, procesu, udalosti, stavu P. V istom zmysle možno hovorit' o kauzálnej sukcesívnosti (porov. Hirschová, 2013).

V jazykovom obraze sveta sa so spojkou $\boldsymbol{k y ́}^{\boldsymbol{m}} \boldsymbol{m}^{1}$ rozlišujú významy a) objektívnych dôvodov (okolností); b) subjektívnych dôvodov (presvedčenia, úmyslov).

Objektívne dôvody sa prezentujú ako okolnosti, interpretované prevažne z pozície pozorovatel'a:

(1) Inštinktívne cúval dovtedy, kým ${ }^{1}$ sa chrbtom neoprel o múr.

(2) Pozeral za ním, až kým ${ }^{l}$ neodbočil na Prvú Avenue.

V súvetí sa spája imperfektív nadradenej vety a perfektív vedlajšej vety, ktorý fixuje akoby konečnú fázu procesu cúvania, pozerania, ktoré sú ukončené fázou opretia sa, odbočenia a pod. Udalost' v Q sa „odčleňuje“ od aspektuálnej sémantiky a prechádza do významu zavíšenia alebo prerušenia; v dôsledku čoho sa ukončuje alebo prerušuje situácia $\mathrm{v} \mathrm{P}$, ktorá je lokalizovaná na pozadí udalosti v $\mathrm{Q}$. 
Subjektívne dôvody sa prejavujú ako úmysel alebo odhodlanie hovoriaceho:

(3) Zostaneme dovtedy, kým $^{I}$ bude treba. (SSSJ)

(4) Nepohnem sa od stola, kým ${ }^{l}$ sa nenaučím.

Majú egocentrickú podstatu a otvárajú priestor pre modálne častice: určite, isto, zrejme, bezpochyby, dozaista a pod.:

(5) Tento zvuk vo mne [určite, isto, zrejme, bezpochyby, dozaista] ostane, kým $^{l}$ budem žit'.

Špecifikom spojky $k y^{\prime}{ }^{l}$ je expletívna negácia slovesného predikátu $\mathrm{v} Q$ (porov. эксплетивное отрицание - Падучева, 2014), ktorá v skutočnosti $S_{2}$ nepopiera, lebo vyjadruje akoby opačný zmysel, má prevrátenú polaritu kladu a záporu, porov.:

(6) Chvíl'u zapekajte, kým ${ }^{l}$ sa syr nerozpustí [t. j. kým sa syr rozpustí].

Konštrukcia „P, kým ne-Q“ naznačuje, že situácia v P je súčast’ou stavu nenastúpenia udalosti Q (porov. Падучева, 2008). Situácia v P znamená akoby subinterval (moment) na intervale Q (porov. dokonavý vid predikátov):

(7) Štát by mal preto maximálne využit' vôlu a nadšenie našich mladých vedcov, kým úplne nezoslabne.

(8) Experimentujte, kým $^{l}$ neprídete na to, čo vám najviac vyhovuje.

Expletívna negácia sa v slovenčine často vyskytuje v spojeniach až kým:

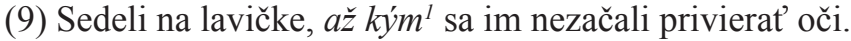

(10) Tento proces sa opakuje, až kým $m^{I}$ produkt nezíska požadovanú chut'.

Častica $a z ̌$ zdôrazňuje hraničnost' situácie $\mathrm{S}_{2}$, ktorá ukončuje dej, činnost', proces, stav v $\mathrm{S}_{1}$, a to bez ohl'adu na temporálnu lokalizáciu (minulost', budúcnost', prítomnost') a na diatézu. Má pragmatiku zámernej zmeny, ked’že v $\mathrm{S}_{1}$ sú predikáty s významovým odtienkom 'kontrolovatel'nosti' (porov. Булыгина, 1982). Podl'a typu predikátu môže mat' aj význam očakávanej zmeny, a to vtedy, ked' $S_{1}$ je ciel'om, intenciou $\mathrm{S}_{2}$ :

(11) Kopali tak dlho, kým ${ }^{l}$ nenarazili na vodu.

Pragmatický význam neočakávanosti, prekvapenia vnáša príslovka zrazu (jej synonymá odrazu, naraz, neočakávane sa podla korpusových údajov v tomto kontexte nevyužívajú):

(12) Rieka pokojne tečie krajinou, kým ${ }^{l}$ zrazu nenarazí na tvrdé skaly.

Ak je negácia aj v nadradenej vete, a to tak explicitná (doklad 13a), ako aj implicitná, ktorá vyplýva zo sémantiky slovies typu odmietat', odopriet', zamietnut', zavrhnút' a pod., negácia $\mathrm{v} Q \mathrm{Q}$ nie je expletívna, porov. ich synonymické pendanty: 
(13a) Komisia nezverejní údaje, $k y ́ m^{l}$ nebudú všetky spracované.

(13b) Komisia zverejní údaje, ked' budú všetky spracované.

(14a) Polícia im odmieta pomôct', kým $m^{l}$ nie sú v ohrození života.

(14b) Polícia im pomôže, ked' budú v ohrození života.

V ruštine je spojka $k^{\prime} m^{l}$ v kontexte negácie (пока не Q) posudzovaná ako jej samostatný význam. Môže to súvisiet's šasticou $\mu$, ktorá je, na rozdiel od slovenčiny, autonómnou lexémou.

V slovenčine je komunikačne preferovaná l’avostranná kolokácia so slovesom trvat', ktoré persistenciu $\mathrm{P}$ (trvanie v čase) prezentuje ako explicitnú duratívnost' situácie $\mathrm{S}_{1}$ (umožňuje to sémantika a nedokonavý vid slovesa trvat). Vlastný obsah súvetia vyjadruje Q (kým ${ }^{l}$-veta) a $\mathrm{P}$ ju len „rámuje“ (má platnost' pozadia, porov. Daneš, 1985). Obe súčasti súvetia vykazujú nesamostatnost' situácií $S_{1}$ aj $S_{2}$ a majú pevný vetosled. V P sa slovesom trvat' podčiarkuje dôležitost' 'časového rozpätia' pre obsah súvetia. Sloveso trvat' má v slovenčine tri aktanty: čo, komu, ako dlho. Sémantika slovesa neumožňuje použitie tvarov prvej a druhej osoby, takže sloveso trvat' stojí vždy v tvare tretej osoby jednotného čísla prítomného, minulého alebo budúceho času a viaže na seba subjekt v datíve (komu). Aktant čo býva často fakultatívne vyjadrený pomocou podmetového výrazu to:

(15) Trvalo to večnost', kým ${ }^{l}$ sme sa vyviezli až hore.

(16) Trvalo to desat' rokov, $k^{\prime} m^{l}$ som sa z toho dostala.

Pragmatické hodnotenie času ako subjektívne krátky alebo dlhý interval sa prejavuje vo výbere lexikálnych prostriedkov s temporálnym významom: dlho, večnost', chvil'a, čas, dost', hodne, vyše a pod.:

(17) Trvalo nám dost’ dlho, kým ${ }^{l}$ sme našli vilu Slovanského ústavu.

Ponímanie času ako subjektívne neurčitého časového intervalu podčiarkujú neurčité deiktiká nejaký, určitý, istý:

(18) Určitý čas bude trvat', kým ${ }^{l}$ sa trhové podiely urovnajú.

Objektívne hodnotenie času vyjadrujú lexikálne prostriedky ako hodina, den̆, týždeň, mesiac, rok (sekunda, minúta sú pragmaticky menej aktuálne), ktoré zároveň presuponujú možnost' použitia kvantitatívnych konkretizátorov:

(19) Trvalo nám dve hodiny, $k^{\prime} m^{l}$ sme sa vymotali z parížskej zápchy.

(20) Hasičom trvalo dvadsat štyri hodín, kým ${ }^{l}$ oheň v lese zlikvidovali.

Typickým znakom tohto typu sú imperfektívne tvary slovesa trvat', irelevantné $\mathrm{k}$ dobe komunikácie. Nedokonavý vid slovesa trvat' súvisí s tým, že P prezentuje 
akoby komentár hovoriaceho alebo pozorovatel'a, zatial' čo dokonavý vid slovies v Q naznačuje, že situácia $S_{2}$ má význam finálnej, ciel’ovej fázy udalosti.

Pre konštrukcie so slovesom trvat' v P sú prirodzenejšie kontexty naratívnej retrospekcie, prítomný a budúci čas je orientovaný prevažne do zóny mentálnych, resp. sociálnych stavov hovoriaceho:

(21) Zakaždým mi chvíl’u trvá, kým ${ }^{l}$ si na zmenu zvyknem.

(22) Divákovi ešte potrvá, $k^{\prime} m^{I}$ sa prepracuje k tomuto poznaniu.

Význam 'prebiehania v čase' majú slovesá plynút', uplynút', ktoré sa uplatňujú tak v P, ako aj v Q:

(23) Kým ${ }^{l}$ bude sobášs, uplynú aj dva roky.

(24) Počkal som, kým uplynie zákonná lehota 30 dní, <..>.

Vyjadrenie subjektu deja, a tým aj použitie osobných slovesných tvarov, umožňuje sloveso čakat' a jeho deriváty počkat', vyčkat', vyčkávat' (sloveso dočkat' nie je doložené). Má význam 'určitý čas strávit' čakaním', adverbiálny modifikátor označuje miesto, kde sa činnost' konala, resp. bude konat'. V Q je formou futúra a expletívnej negácie vyjadrená potenciálna udalost', ktorá ukončí $\mathrm{P}$ a zároveň ciel' čakania:

(25) Čakali na chodníku, kým ${ }^{l}$ nebudú mat’ zelenú. (SSSJ)

(26) Počká, $k$ ḱm $^{l}$ nedostane viac informácií od vyšetrovatelov.

(27) Bude čakat' pri vchode tak dlho, kým $m^{l}$ sa syna nedočká.

(28) <...> ukryl sa pod schodiskom a vyčkal, kým ${ }^{l}$ pracovníci nezamknú vchod do budovy.

Spojka kým ${ }^{l}$ je synonymická so spojkou $a \check{z}^{l} \mathrm{~s}$ významom objektívnych okolností, po ktoré trval alebo bude trvat' dej alebo stav nadradenej vety. Podmienkou použitia spojky ažl je afirmatívny predikát $\mathrm{v}$ Q, zatial' čo spojka kým ${ }^{l}$ sa spája tak s afirmatívnym, ako aj negovaným (expletívnym) predikátom v Q:

(29a) Počká, $a z^{l}$ sa rozvidnie. (KSSJ)

(29b) Počká, kým ${ }^{l}$ sa (ne)rozvidnie.

V doklade (30a) M. Hirschová (2011, s. 156) poukazuje na skutočnost', že imperfektív udalostných slovies implikuje prechodný bod medzi presuponovaným začiatočným a dosiahnutým konečným stavom perfektíva:

(30a) Opravoval auto tak dlho, $a \check{z}^{l}$ ho nakoniec opravil.

Analogické súvetie so spojkou kým si vyžaduje v Q negovaný tvar dokonavého slovesa, ked'že v P je smerovanie $\mathrm{k}$ dosiahnutiu výsledku (opravoval) a neurčitá duratívnost' (dlho):

(30b) Opravoval auto tak dlho, kým ho nakoniec neopravil. 
Určitá duratívnost' (dve hodiny) vylučuje negáciu v Q:

(30c) Opravoval auto dve hodiny, kým / [ažl] ho nakoniec opravil.

Nekompatibilné sú významy spojky $a \check{z}^{2}$, ktorá vyjadruje okolnost', počas ktorej bude prebiehat' dej nadradenej vety (doklad 31), a význam spojky až³, ktorý vyjadruje okolnost', po ktorej sa uskutoční dej nadradenej vety (doklad 32):

(31) $A \check{z}^{2}\left[{ }^{*} K y m^{l}\right]$ pôjdeme domov, bude určite pršat'. (KSSJ)

(32) $A z^{3}\left[{ }^{*} K^{\prime} m^{I}\right]$ sa vrátime, dokončíme robotu. (KSSJ)

Spojka kým ${ }^{l}$ je čiastočne zamenitel’ná príslovkovými zámenami pokial', dokial', dokým, pokým, ked’že v ich sémantike je obsiahnutá idea koncového limitu, ktorú majú prefixálne morfémy po-, do-:

(33) Pokial' / [dokial' / kým $\left.{ }^{I}\right]$ bol zdravý, pracoval dobre.

Spojka kým ${ }^{l}$ je komunikačne najpreferovanejšou. Môže to súvisiet' jednak s jej sémantickými predispozíciami a jednak s tým, že uprednostňuje vetosled $P, k y ́ m^{l} Q$. Psychologické výskumy časových súvetí (porov. Фёдорова, 2005) totiž ukazujú, že do operatívnej pamäti recipienta sa rýchlejšie dostáva a interpretuje hlavná veta na iniciálnej pozícii.

2.2 Spojka $\boldsymbol{k y ́}^{2}{ }^{2}$ spája také situácie $\mathrm{S}_{1}$ a $\mathrm{S}_{2}$, ktoré vyjadrujú časovú následnost' dejov, činností, procesov, udalostí, stavov: „P skôr/prv kým Q“. Význam následnosti predpokladá: (a) časový úsek, zahrňujúci moment prehovoru a tiež momenty do a po ňom, ktoré sú dostatočne blízke, aby si s ním zachovali spätost'; (b) situáciu, ktorá sa uskutočňuje $\mathrm{v}$ tom istom reálnom alebo nereálnom priestore, $\mathrm{v}$ ktorom sa nachádza hovoriaci a v ktorom je účastníkom alebo pozorovatel'om.

Ide o špecifikovanú následnost', ked' hlavný dej nastal alebo istý čas prebiehal, alebo začal platit' ešte pred zavŕšením vedlajšieho deja (Ferenčíková, 1986). Osobitost' tohto typu spočíva v tom, že spája ideu deja a ideu udalosti. Gramaticky sa to prejavuje tak, že udalost' je obsahom nadradenej vety a vždy je vyjadrená slovesom v dokonavom vide. Dej vyjadrený vedl'ajšou vetou so spojkou kým môže byt' aj dokonavý, aj nedokonavý, sémanticky musí presuponovat' možnost' prerušenia deja a možnost' $k$ jeho návratu (porov. doklady 38 a 39). Tento typ vykazuje nesúlad medzi vetosledom a časovým poradím udalostí a umožňuje interpretáciu akoby z dvoch perspektív: a) situácia $\mathrm{v} \mathrm{P}$ predchádza situácii $\mathrm{v} \mathrm{Q}$; b) situácia $\mathrm{v} \mathrm{Q}$ nasleduje po situácii $v \mathrm{P}$.

Interpretáciu „situácia v $\mathrm{P}$ predchádza situácii v Q“ podporuje parafrázovanie a použitie spojok skôr než, prv než, predtým než, porov.:

(34a) Kým² prišiel lekár, pacient zomrel.

(35b) Do príchodu lekára pacient zomrel.

(36c) Skôr než prišiel lekár, pacient [už] zomrel. 
Predchádzanie (temporálna predčasnost') umožňuje tak jedného aktora dvoch rôznych dejov, ako aj dvoch (resp. viacerých) aktorov dvoch (resp. viacerých) dejov. V nadradenej vete sa otvára možnost' na použitie príslovky už, ktorá podčiarkuje význam zavíšenia, zakončenia deja (príznak + telickost').

Interpretácia „situácia v Q nasleduje po situácii v P“ reflektuje prirodzený sled udalostí - najprv jej napísal lístok, potom sa pobalil; najprv vyzrel von, potom vyšiel von. To znamená, že P označuje činnost', ktorá viedla $\mathrm{k}$ nástupu Q:

(37a) $K y m^{2}$ sa pobalil, napísal jej lístok.

(38a) $K y m^{2}$ vyšiel z domu, vyzrel von.

Následnost' (temporálna následnost') presuponuje jedného aktora a otvára možnost' na použitie operátora potom, čo, resp. príslovky ešte, ktorá tiež vyjadruje, že nejaký dej sa uskutoční pred určitou časovou hranicou, porov.:

(37b) Pobalil sa až potom, čo jej napísal lístok.

(37c) $K y m^{2}$ sa pobalil, ešte jej napísal lístok.

(38b) Kým² vyšiel z domu, ešte vyzrel von.

Spojka kým² má ukotvený význam 'trvania', preto sa spája so slovesami, ktoré vyjadrujú neukončenost' deja (príznak - telickost'). Z tohto dôvodu je sémanticky prijatel'nejšie sloveso vyjst' (doklad 38), lebo presuponuje možnost' návratu. V ruštine sa použitie slovesa odist' (yŭmu) považuje za anomáliu, podobne ako predikáty typu umriet' (умереть), ked’že vyjadrujú nezvratný stav (porov. Падучева, 2014). V slovenčine je sloveso odist ${ }^{l}$ akceptovatel'né, ked’že znamená 'vzdialit' sa' a nevylučuje možnost' návratu:

(39) Lenže $k y ́ m^{2}$ odišiel z domu, preobliekol sa do druhých nohavíc.

Spojka kým $m^{2}$ často funguje v súvetiach vyjadrujúcich akoby epizodickú postupnost' viacerých situácií:

(40) Čupla si k trezoru, počkala, $k y ́ m^{2}$ sa jej upokoja ruky, a pomaly, sústredene začala po jednom stláčat' rad klávesov <...>

Prirodzené prepojenie časovej následnosti a protikladnosti (podobne ako v kým $m^{4}$ ) vyjadrujú antepozičné spojenia kým spočiatku, kým zo začiatku, kým najprv, kým sprvu. V nadradenej vete sú obligatórne temporálne náprotivky typu teraz, po čase:

(41) $\mathrm{Ký}^{2} \mathrm{~m}^{2}$ zo začiatku čerpali informácie z publikácií, teraz je to predovšetkým internet, $<\ldots>$.

(42) Kým ${ }^{2}$ najprv produkt sugeroval, že mení tvár hudby, po čase ju reálne zmenil.

Spojka $k y^{2}{ }^{2}$ sa v tomto význame dostáva do konfliktu systematizácií (v zmysle konkurenčných vzt’ahov k iným operátorom), ked’že v slovenčine identický význam i funkciu zastupujú spojky skôr ako, skôr ně̆, predtým než, prv než: 
(43) Kým² / [Skôr ako / Skôr než / Predtým než / Prv než] sme dorazili na miesto činu, vyparil sa.

(44) Skôr ako / [(do)kým²] stihol dobehnút', spadol aj on.

(45) Prv než / [Kým²] odídeš, zavolaj! (KSSJ)

Význam následnosti v slovenčine vyjadrujú aj spojky $\boldsymbol{k e d}, \boldsymbol{a z ̌}$ ked', ktoré však so spojkou $k y^{2} m^{2}$ nie sú zamenitel'né, ked’že vyjadrujú vzájomne opačnú perspektívu v opise udalostí, porov.:

(46a) Ked' vošiel do izby, zapálil svetlo, t. j. najprv vošiel do izby, potom zapálil svetlo;

(46b) Kým² vošiel do izby, zapálil svetlo, t. j. najprv zapálil svetlo, potom vošiel do izby;

(47a) Prišiel, až ked' sa rozvidnelo, t. j. ked' prišiel, svitalo;

(47b) Prišiel, kým ${ }^{2}$ sa rozvidnelo, t. j. prišiel pred svitaním.

Sémantický rozdiel medzi nimi je teda $\mathrm{v}$ tom, že spojka kým² presuponuje situáciu $\mathrm{S}_{1}$, ktorá sa uskutočnila 'dovtedy, kým' sa zrealizovala situácia $\mathrm{S}_{2} \mathrm{v}$ podradenej vete; spojka ked' presuponuje situáciu $S_{2} v$ bode, v ktorom sa (ne)realizovala / (ne)zrealizovala situácia $\mathrm{S}_{1} \mathrm{v}$ nadradenej vete:

(48) $K y m^{2}$ prišli hasiči, podarilo sa nám oheň uhasit’.

(49) Ked' prišli hasiči, už sa nedalo pomôct'.

2.3 Spojka $\boldsymbol{k y ́}^{3}$ spája situácie $\mathrm{S}_{1}$ a $\mathrm{S}_{2} \mathrm{~s}$ identickým časovým priebehom v Q a v P: „Q zatial' čo P“. O reálnej či predpokladanej súbežnosti, synchrónnosti dvoch či viacerých dejov hovoríme vtedy, ked’ dej nadradenej vety nastal v úseku vymedzenom dejom časovej vedlajšej vety (Ferenčíková, 1986; Žigo, 2010). V prípade súbežnosti neplatí implikatúra prirodzeného sledu udalostí, ale aktuálne členenie, ktoré spadá do kompetencií a preferencií hovoriaceho ako pozorovatel'a. Súbežnost' častejšie presuponuje dvoch aktorov:

(50) $K y m^{3}$ bol muž na nákupe, žena zrejme bola na prechádzke so stafordširským teriérom, ktorý ju napadol.

(51) $\mathrm{Ký}^{3} \mathrm{~m}^{3}$ si zatierač odskočil doplnit' farbu, fotoreportér SME zvečnil torzo miznúceho nápisu.

Súbežnost' dvoch (a viacerých) činností jedného aktora je možná len vtedy, ked' činnosti sú vzájomne zrealizovatel'né, a teda sémanticky kombinovatel'né, porov.:

(52) Kým ${ }^{3}$ si varil kávu, premýšl’al, <...> .

Retrospektívnu pozíciu hovoriaceho ako pozorovatel’a najčastejšie fixuje minulý čas (označovaný aj ako rozprávačský čas). Uplatňuje sa naratívny režim, v ktorom pozorovatel' reprodukuje dianie akoby zo svojho uhla pohl'adu, a tým mu dáva 
priestor pre epistemické častice zrejme, asi, pravdepodobne, isto, istotne, určite, nepochybne.

Sloveso v Q môže byt' v prítomnom alebo budúcom čase len v rečovom (dialogickom) režime, a vtedy aj v nadradenej vete je prézent alebo futúrum. V doklade (53) má dialogický režim podobu vnútornej reči, porov.:

(53) „Ja robievam aj tri. Napríklad - kým ${ }^{3}$ teraz s vami telefonujem, uzatváram materiály na inauguráciu a rozmýšlam, ako budem uvádzat' knihu <... “".

(54) $\mathrm{Ky}^{\prime} \mathrm{m}^{3}$ bude [ona] spat’, objedná [on] termosky horúcej čokolády.

Виктор С. Храковский (2005) rozlišuje úplnú súbežnost' situácií $\mathrm{S}_{1}$ a $\mathrm{S}_{2}$ (полная одновременность) a neúplnú súbežnost' (неполная одновременность). Pri úplnej súbežnosti situácia $S_{1}$ sa uskutočňuje na pozadí pokračujúcej situácie $S_{2}$ :

(55) Kým ${ }^{3}$ pršia bomby, podpisujú sa kontrakty, registrujú kontrakty, kladú sa ropovody, ničia sa prírodné zdroje, privatizujú vodné zdroje a demokracia je podkopávaná.

Čiastočná súbežnost' je možná v naratívnom režime s významom protikladnosti; fakultatívna častica $u z ̌$ vnáša význam okamžitého nastúpenia deja, činnosti, procesu, príslovka zrazu význam náhlosti, neočakávanosti:

(56) $K y m^{3}$ sa jedna konferencia skončí, už začína nič neriešiaca druhá <...>.

(57) $\mathrm{Kým}^{3}$ si rozprávala, zrazu sa mi všetko vyjasnilo, spoznal som sa $<\ldots>$.

Súbežnost' dvoch a viacerých dejov z hl'adiska intenzity (lat. total gravis) vyjadrujú imperfektívne slovesné tvary Q aj $\mathrm{P}$, irelevantné $\mathrm{k}$ dobe komunikácie:

(58) $\mathrm{Ký}^{3}{ }^{3}$ Marienka číta, Jurko si (zatial') píše domáce úlohy (porov. Sokolová - Žigo, 2014, s. 43).

V tomto význame je spojka kým ${ }^{3}$ synonymná so spojkami zatial’ $\check{c o s}^{I}$ (t. j. v jej časovom význame) a medzitým čo. Spája ich význam špecifikovanej nekontrastívnej súčasnosti (Žigo, 2010, s. 201):

(59) Zatial' čo / [kým $\left.\mathrm{k}^{3}\right]$ spal, spŕchlo.

(60) Medzitým čo / [kým $\left.{ }^{3}\right]$ čítal, obed sa uvaril. (KSSJ)

Význam súbežnosti v slovenčine vyjadruje aj spojka ked', porov.: Ked' prišiel domov, všetci už spali (SSSJ). V tomto kontexte spojky nie sú plne zamenitel'né, ked'že spojka ked' je tu časovým orientátorom udalosti (akoby vyjadrovala časový bod, porov. Oravec, 1971, s. 3) a spojka kým je časovým orientátorom duratívnosti a zdôrazňuje skutočnost', že situácia $S_{2}$ sa realizuje výhradne so situáciou $S_{1}(X p a-$ ковский, 2005, s. 51):

(61) Kým ${ }^{3}$ som varila obed, čajník stál na sporáku.

(62a) Ked' som varila obed, čajník stál na sporáku. 
Príklady, ktoré uvádza Е. В. Падучева (2014, s. 342), sa odlišujú v tom, že doklad (61) akcentuje prítomnost' čajníka na sporáku počas prípravy obeda (a potom jeho neprítomnost'), doklad (62a) nazerá na P z perspektívy časového intervalu Q (čo bolo d'alej s P nie je dôležité) a v slovenčine umožňuje použitie ukazovacieho príslovkového zámena vtedy:

(62b) Čajník stál na sporáku vtedy, ked’ som varila obed.

2.4 Spojka $\boldsymbol{k y ́}^{4}$ spája situácie $\mathrm{S}_{1}$ a $\mathrm{S}_{2}$ s protikladnými faktami v P a v Q a s identickou časovou lokáciou. Čas je pritom len vonkajším rámcom alebo javiskom (Filkorn, 1998, s. 282). Tento typ súvetia je zacielený na vyjadrenie paralelnej obsahovej línie dvoch propozícií, ktoré spája polarita dvoch a viacerých faktov:

(63) Trh vnímame ako nástroj na dosiahnutie ciel’a, kým ${ }^{4}$ rodinu vnímame ako ciel' samotný.

(64) Jemu sa darilo, kým ostatní zápasili s problémami. (KSSJ)

(65) $K y m^{4}$ sa diváci bavia, postavy žánrovo trpia.

Hovoriaci vystupuje v naratívnom režime ilokučnej kontradikcie, t. j. tvrdenia, v ktorom sú koncepty vo vzt’ahu priameho alebo nepriameho protirečenia. Do kontrastu sa tak dostávajú jazykové prostriedky aj systémovej, aj kontextovej antonymie. Poradie faktov odráža konfrontačnú perspektívu, ktorá je v kompetencii hovoriaceho, takže teoreticky je sémanticky aj gramaticky možné aj inverzné poradie propozícií:

(66a) Mne išlo predovšetkým o hudbu, kým ${ }^{4}$ divákom o gagy a skeče.

(66b) Kým divákom išlo o gagy a skeče, mne išlo predovšetkým o hudbu.

(66c) Divákom išlo o gagy a skeče, $k$ kým $^{4}$ mne išlo predovšetkým o hudbu.

Korpusový materiál ukázal silu pragmatických systematizácií, ktoré viac preferujú poradie najprv ,pozitívna tonalita informácie $\mathrm{v}$ P, resp. Q, potom negatívna tonalita informácie v Q, resp. P“, porov. darit'sa-zápasit' (doklad 64); hrat's niekým - hrat' proti niekomu (doklad 71); bavit'sa - trpiet' (doklad 65); ostávat' - menit' sa (doklad 69) a pod.

Preferenčné ponímanie faktov hovoriaci vyjadruje aj prostredníctvom častíc najmä, hlavne, predovšetkým, zrejme:

(67) $K y ́ m^{4}$ spojky $a j-a j$, ani-ani sú komunikačne späté predovšetkým s umeleckým textom; spojky $i-i$,jednak - jednak sú operátormi hlavne v náučnom texte (Kesselová, 2013b, s. 109).

Pragmatický postoj s náznakom prípustky prezentujú spojenia avšak kým; lenže, kým:

(68) $A v s ̌ a k ~ k y ́ m m^{4}$ v roku 1990 dostali vysoké školy na jedného študenta asi 44-tisíc korún, v roku 1999 sa odhad pohybuje len pod 10-tisíc korún.

(69) Lenže, kým ${ }^{4}$ erby ostávajú, život sa mení. 
Temporálnost' kontradiktorických viet explicitne vyjadrujú výrazy vtedy - kým teraz, predtým - kým teraz. Do protikladu sa dostávajú nielen fakty v P a Q, ale aj préteritum a aktuálny prézent:

(70) Vtedy to bola len príprava na život, kým $^{4}$ teraz je to sám život.

(71) Predtým som hrávala s Radkou a Jankou, kým teraz som nastúpila proti $\operatorname{nim}$.

Synonymický vzt'ah spojok kým ${ }^{4}$ a zatial' č $\boldsymbol{\sigma}^{2}$ (t. j. v jej odporovacom význame) uvádza aj Krátky slovník slovenského jazyka (2003), porov.:

(72) Všetci sa zabávali, zatial' čo / [kým $\left.{ }^{4}\right]$ my sme tam len stáli.

Podobne sa správa česká spojka zatímco, porov.: „časový význam spojky zatímco mívá tendenci přecházet ve význam kontrastně konfrontační, jestliže souběžné děje jsou v nesouladu“ (Mluvnice češtiny 3, 1987, s. 475).

Prirodzené prepojenie protikladnosti a času dokumentuje možnost' výmeny spojky kým ${ }^{4} \mathrm{v}$ spojeniach $k y ́ m^{4}$ teraz za odporovacie spojky ale, avšak, zato, lenže v spojeniach ale teraz, avšak teraz, zato teraz, lenže teraz:

(73) Vtedy sme aspoň hrali, kým teraz / [ale teraz / avšak teraz / zato teraz, lenže teraz] to nejde nikomu $\mathrm{z}$ nás.

Zatial' čo v spojeniach so spojkami ale, avšak dominuje odporovací význam, $\mathrm{v}$ spojeniach so spojkami kým, zato, lenže vzt’ah protikladnosti má odtienok prípustky.

\section{ILOKUČNÉ FUNKCIE SPOJKY KÝM}

Spojka kým má predpoklady byt' ilokučná, a to vtedy, ked' vedl'ajšiu vetu Q nespája len s propozičným obsahom nadradenej vety $\mathrm{P}$, ale aj s jeho ilokučnou hodnotou (v terminológii, ktorú uvádza Е. В. Падучева, 1985 - иллпокутивной компонентой). Nazeranie na ilokučné funkcie spojky kým posúva interpretáciu do ponímania súvetia ako komunikačného aktu, konštituujúceho interpersonálny vzt’ah medzi hovoriacim a adresátom. Pod ilokučnou funkciou spojky sa spravidla rozumie také jej použitie, v ktorom spojka vyjadruje vzt’ah medzi zmyslom vedl'ajšej vety a rečovým aktom, ktorý zodpovedá nadradenej vete (porov. Иорданская, 1988).

Súvetia, ktoré sú realizované $\mathrm{v}$ dialogickom režime, majú prevažne status replík. Určujúca je perspektíva hovoriaceho a jeho zámer dosiahnut' istý komunikačný efekt, t. j. ovplyvnit’ verbálne, kognitívne, emocionálne a pod. správanie adresáta (porov. Dolník, 2013). Komunikačný zámer sa koncentruje v nadradenej vete (v P), ktorá vyjadruje dominujúcu ilokúciu (porov. Encyklopedický slovník češtiny, 2002, s. 176). V jej rámci sa celkom prirodzene predpokladá uplatňovanie vôlovej, istotnej, postojovej a hodnotiacej modálnosti. Spojenie temporálnosti a kontradickosti 
(s rôznou mierou prevahy jednej alebo druhej zložky) vytvára predpoklady na realizovanie v Q širokej palety tzv. subsidiárnych ilokúcií. Subsidiárne ilokúcie Q majú k P vzt'ah napr. temporálnej limitatívnosti (spojka kým), zdôvodnenia (spojka lebo), resp. podmienky (spojka $a k$ ), porov.:

(74a) Nechod' von, kým ${ }^{l}$ prší (temporálna limitatívnost' P na pozadí Q);

(74b) Nechod' von, lebo prší (zdôvodnenie);

(74c) Nechod' von, ak prší (podmienka).

V doklade (74a) dôvod v Q (prši) je motívom vyslovenia zákazu, odporúčania nevykonat' činnost' v P. Dôvod v Q ohraničuje nielen trvanie P, ale aj platnost' zákazu. Subsidiárne ilokúcie majú akoby podpornú funkciu, ale zároveň plnohodnotný podiel na konštituovaní celkového zmyslu súvetnej výpovede (porov. Encyklopedický slovník češtiny, 2002; Hirschová, 2004).

Súvetné propozície so spojkou kým sa uplatňujú tak vo všeobecných, generických, ako aj jedinečných, singulárnych vetách. Dialogický režim totiž nevylučuje možnost' „citátového“, intertextuálneho použitia prísloví, porekadiel, aforizmov:

(75) Nekrič hop, kým $m^{l}$ nepreskočíš.

(76) $K y m^{4}$ bude teror, nebude mier.

V singulárnych súvetných propozíciách sa spojka kým uplatňuje ako súčast' asertívnej, direktívnej, interogatívnej, (ne)satisfaktívnej, komisívnej a admonitívnej komunikačnej funkcie (v ponímaní M. Grepla, 1998b).

$\mathrm{K}$ interakčným podmienkam patrí to, že informácie v Q sú komunikačne neautonómne, rozlišuje sa v nich personálnost' a impersonálnost' (porov. pršat'-impersonálny dej). Personálnost' v Q vyjadruje vzt’ah predikátu k účastníkovi komunikácie: kým ja/my vyjadruje vzt'ah $\mathrm{k}$ hovoriacemu, napr. v ilokúcii odhodlania, slubu a varovania; kým ty/vy vzt’ah k adresátovi, napr. v ilokúcii upozornenia, obáv, výčitky; kým on/ona/oni vzt’ak k tretej osobe (osobám) komunikácie, napr. v ilokúcii ponaučenia a prosby. Impersonálnost’ sa prejavuje najmä v ilokúcii návodu.

3.1 V asertívnej KF sa realizujú ilokúcie konštatovania, odhodlania a námietky. Ich integrálnou súčast'ou je zámer hovoriaceho oboznámit' adresáta s novými skutočnost’ami, ktoré sú z jeho pohl'adu relevantné.

Konštatovanie, tvrdenie opisuje stav vecí, ktorý hovoriaci eviduje ako pravdivý (v intenciách komunikačného princípu úprimnosti). Otvára možnost' uplatnenia spojky kým vo všetkých jej sémantických funkciách:

(77) Istý čas mi potrvá, kým $m^{I}$ znovu nadobudnem sebavedomie.

(78) $K y^{\prime} m^{2}$ som sa dostal ku klúčom, bola stodola v plameňoch <... .

(79) $\mathrm{Kým}^{3}$ som študoval, aktívne som boxoval za Atom Jaslovské Bohunice v Trnave.

(80) $\mathrm{Kým}^{4}$ ja som sa zabávala, on mlčky čakal. 
Emocionálna a hodnotiaca angažovanost' hovoriaceho je v nich minimalizovaná. Konštatovanie prináša fakty a udalosti v časovej lokalizácii préterita, prézenta, resp. futúra. Doklady poukazujú na častost' koncentrácie na perspektívu ja aj v Q. Z pohl'adu komunikačných funkcií platí, že tvrdenie je síce primárnou komunikačnou funkciou výpovedí s časovým operátorom (Kesselová, 2010, s. 380), ale spojka kým stavia do popredia aj iné ilokúcie, takže funguje v kontexte „upozadeného“ tvrdenia (снятой утвердительности, porov. Падучева, 2014).

Odhodlanie je prezentované ako úmysel hovoriaceho konat' v intenciách vlastného (pevného) rozhodnutia, ktorého správnost’ hovoriaci považuje za nespornú. Časovo je situované do prítomnosti alebo budúcnosti:

(81) Kým $^{l}$ žijem, vinohradu sa nevzdám!

(82) Budem dojčit' dovtedy, kým $^{l}$ budem mat' mlieko.

(83) Neodídem, kým $^{l}$ sa so mnou neporozprávaš.

Odhodlanie signalizuje tematizáciu preferenčného postoja, vy̌̌ší stupeň subjektívneho presvedčenia hovoriaceho o platnosti komunikovaného obsahu, takže sa spája s epistemickou aj voluntatívnou modalitou. Vyjadruje zámer s modálnou hodnotou 'mat' úmysel' (porov. Grepl, 1998a, s. 165 - 166) a môže vyznievat' proklamačne.

V námietke je obsiahnuté ohradenie sa, odmietavé stanovisko, protest. Tým sa otvára priestor pre explicitné presadzovanie vôle hovoriaceho a používanie modálnych relátorov. Napríklad, pri externej negácii relátora chciet', je jeho primárnou funkciou explicitné vyjadrenie úmyslu, vôle nerealizovat dej, ktorý je v kompetencii hovoriaceho (porov. Ivanová, 2010).

(84) Nechceme to komentovat', kým ${ }^{l}$ nie je náš prípad ukončený.

(85) Nebudem trčat' doma a viest' domácnost', kým ${ }^{4}$ ty budeš flámovat'.

Použitie podmieňovacieho spôsobu, ktorý tým, že vyjadruje neaktuálny podmienený dej, tlmí razantnost' namietania:

(86) Nerád by som však predbiehal, kým $^{l}$ nebudú definitívne podpísané zmluvy, <..>.

Ciel'om takýchto súvetí je upozornit' na skutočnosti alebo okolnosti, ktoré sú $\mathrm{v}$ rozpore s názormi, presvedčením alebo tvrdením hovoriaceho. Ich primárnou funkciou je vyjadrit' vôl'u, resp. úmysel hovoriaceho nerealizovat' $S_{1}$, pokial' trvá $S_{2}$. Presuponujú tak možnost' použitia v P častíc vyjadrujúcich rôznu mieru epistemickej modality: vari, predsa, azda, nebodaj, hádam; určite, isto, bezpochyby a pod.

3.2 Direktívna KF je verbálne zameraná na adresáta, takže nadradená veta sa obsahovo koncentruje na jeho činnost', konanie. V P je sloveso v imperatíve, resp. indikatíve. Imperatív nie je v čase komunikácie reálnym dejom. Direktívna ilokúcia je časovo situovaná do prítomnosti alebo blízkej budúcnosti. 
Príkaz, výzva sú autoritatívne nasmerované na vykonanie alebo nevykonanie nejakej činnosti. Predikáty v P majú príznak 'kontrolovatel'nosti', predikáty v Q ich doplňujú o prvky faktívnosti:

(87) Príd' hned' na začiatku, kým ${ }^{l}$ sú ešte vol'né miesta.

(88) Dávaj naňho dobrý pozor, kým ${ }^{l}$ budem preč.

(89) Ostan̆ tam, kým $^{l}$ t’a neprídu vymenit!

(90) Slúb mi, že nespravíš ani krôčik, kým ${ }^{l}$ sa so mnou neporadíš!

(91) Neponáhl'aj sa a zostaň stát' a počkaj, $k y^{\prime} m^{l}$ sa rozvidnie.

(92) Dovtedy nevyjdete z tohto bytu, kým $^{l}$ si to nerozmyslíte!

V súvetiach $(87$ - 89) dominuje adhibitatívny zámer hovoriaceho, ktorým sa usiluje prehovorit', prinútit' adresáta $\mathrm{k}$ realizácii činnosti vyjadrenej v syntakticky nadradenej vete $(\mathrm{P})$. V súvetiach $(90$ - 92) prevláda prohibitatívny aspekt, ked’že hovoriaci sleduje to, aby adresát nerealizoval činnost' dovtedy, kým platia okolnosti uvedené $\mathrm{v} \mathrm{Q}$.

Upozornenie je forma výzvy, snaha hovoriaceho upriamit' pozornost' adresáta na niečo, čo je $\mathrm{v}$ jeho záujme, aby vykonal. Implikuje vzt’ah nutnosti (postulatívnej aj objektívnej), možnosti negatívnych okolností a konzekvencií. Upozornenie sa spája s futúrom v jeho gnómickom poňatí (platnost' dejov sa vzt’ahuje aj na prítomné a minulé deje):

(93) $K y^{\prime} m^{2}$ začnete kopat' základy, budete si musiet' zohnat' niekol'ko desiatok dokumentov $<\ldots>$.

Odporúčanie, ponaučenie sú akoby pokynom na konanie, návodom, vysvetlením niečoho. Súvetia sú časovo umiestnené do prítomnosti alebo budúcnosti:

(94) Ustúp radšej skôr, $k y ́ m^{l}$ ešte môžeš.

Prirodzené je použitie v $\mathrm{P}$,solidárneho“ inkluzívneho $m y$ a indikatívu namiesto imperatívu, resp. spojenia s osobným tvarom slovesa radit:

(95) Ak je vozidlo na boku, neotáčame ho, kým ${ }^{3}$ sú zranení vo vnútri.

(96) A radím ti, ber, kým $m^{l}$ som dobrý, <...>.

Návod je inštruktáž, ako niečo robit' alebo používat'. V Q je pasívnym predikátom daná situácia z perspektívy objektu deja implikujúca rezultatívny význam výsledného stavu, ktorý je ireverzibilný. V P sa využívajú tvary imperatívu 2. osoby plurálu, resp. indikatívu, zvyčajne inkluzívnej 1 . osoby plurálu prézenta činnostných slovies, v Q sú participiálne pasíva v 3. osobe singuláru alebo plurálu:

(97) Varte dovtedy, $k^{\prime} m^{l}$ sa voda neodparí <... .

(98) Varíme, kým ${ }^{l}$ nie je zelenina mäkká. 
Návody sa používajú v komunikačnej sfére bežnej a mediálnej komunikácie. Uplatňujú sa v kulinárskych receptoch, v ktorých spojka kým ${ }^{l}$ prirodzene využíva svoje predispozície na vyjadrenie idey koncového časového limitu v kontexte expletívnej negácie. Návody sú zamýšlané ako potenciálne budúce činnosti adresáta, konajúceho $\mathrm{v}$ intenciách pokynov.

Prosba je zdvorilá, úctivá žiadost' hovoriaceho majúca apelatívny význam. Explicitne ju prezentuje ilokučné verbum prosit' v tvare 1 . osoby jednotného alebo množného čísla. Q je orientované bud' personálne - na 3. osobu alebo osoby, resp. impersonálne.

(99) Prosím t’a počkaj, kým ${ }^{l}$ sa nevráti môj manžel.

(100) Prosíme vás, napíšte nám hned’ teraz, kým ${ }^{l}$ sú vaše dojmy ešte celkom čerstvé.

Tvar imperatívu v P v ilokúcii prosby musí byt’ oslabený funkčným využitím externých lexikálnych prostriedkov, napr. častíc: dobre, však, ktoré na konci súvetia vyjadrujú akoby pobádanie na súhlasnú reakciu:

(101) Len minútku počkajte, $k^{\prime} m^{l}$ to dokončím, dobre?

Návrh je upozornenie na eventuálnu realizáciu, resp. nerealizáciu takej činnosti, ktorú hovoriaci považuje vzhladom na situáciu za adekvátnu. V Q sa konkretizuje temporálny aspekt okolnosti, ktorá limituje P. Hovoriaci nemá istotu, že návrh bude prijatý. Priamym indikátorom návrhu býva performatívne sloveso navrhovat' v príslušných osobných formách. Súčastou návrhu je persuazívnost':

(102a) $K y m^{3}$ ste tu, odoberieme vám zopár kostných štepov.

(103a) Kupujte knihy, kým sú lacné.

V Q sa uvádzajú fakty majúce funkciu argumentov (v jazykovednom, resp. rétorickom ponímaní), vyjadrujúcich zdôvodnenie, porov.:

(102b) Kedž̌e ste tu, odoberieme vám zopár kostných štepov.

(103b) Kupujte knihy, lebo sú lacné.

Zákaz je verbálnym prejavom rozhodnutia hovoriaceho, že adresát nesmie niečo robit', uskutočnit', a to dovtedy, kým v Q platí situácia $\mathrm{S}_{2}$ :

$(104)<\ldots>$ ale polievky $<\ldots>$ sa nesmieš dotknút', kým ${ }^{l}$ sa nevrátim.

(105) Nebudeš otvárat', kým ${ }^{l}$ ja nepoviem.

Expletívna negácia v dokladoch (104 - 105) vyjadruje zákaz činnosti v P do nastúpenia činnosti v Q. Dôsledky nerešpektovania bývajú vyjadrované ako dodatok, vysvetlenie v podobe lebo uvidís, lebo bude zle a pod. 
3.3 Interogatívna KF je iniciovaná ciel’om získat' informáciu, ktorou hovoriaci nedisponuje a o ktorej predpokladá, že ju má adresát a môže ju zdiel'at'. Často sa spája s deliberatívnymi otázkami, ktoré si hovoriaci kladie zároveň akoby aj sebe. Vo význame zist'ovania (potvrdenia alebo popretia faktov) sa používa modálne sloveso $m a t^{\prime} \mathrm{v}$ prítomnom čase alebo $\mathrm{v}$ kondicionále:

(106) Kto má platit' alimenty, kým ${ }^{l}$ nie sme rozvedení?

Interogatívna podoba umožňuje zdiel'anie pochybností, ktoré môžu sprevádzat' emocionálne postoje, napr. rozhorčenia, rozčarovania, počudovania a pod.:

$(107)<\ldots>$ prečo si ho nevyhodil, $k^{\prime} m^{l}$ ešte bola príležitost?

S návrhom sa spája oblast' možného a pripustenie d’alšej alternatívy. Ako vykonávatel’a činnosti môže zahŕňat' aj hovoriaceho. Typická je forma s výrazom čo keby:

(108) Čo keby si najskôr počkala, kým $^{l}$ sa s tebou spoja?

(109) „Čo keby sme si pustili vážnu hudbu, kým ${ }^{l}$ sa to upečie?“ - navrhla som $<\ldots>$.

Uvažovat' o alternatívach možno len vtedy, ked' ide v $\mathrm{P}$ o situáciu $\mathrm{S}_{1}$, ktorá ešte nenastala, ale mohla by nastat', mala by nastat', pravdepodobne nastane, t. j. je hypotetická a zároveň limitovaná nástupom situácie $\mathrm{S}_{2} \mathrm{v} \mathrm{Q}$.

3.4 Satisfaktívna KF sa vzt’ahuje na pochvalnú alebo karhajúcu verbálnu činnost' hovoriaceho, jeho pozitívny alebo negatívny evaluatívny postoj.

Obavy sa spájajú s pocitmi stiesnenosti, strachu, neistoty s možným stavom vecí. Implicitne ich vyjadrujú slovesá timendi: bát'sa, obávat'sa, strachovat' sa; alternatívou je negácia $\mathrm{v}$ slovesných tvaroch tešit :

(110) Netešilo by ma, keby sa niečo stalo, kým ${ }^{3}$ si tu.

Podmieňovací spôsob je motivovaný tým, že P vyjadruje neuskutočnenú podmienku, Q sa viaže na ideu konečnej hranice P. Obavy sú tu v prieniku s ilokúciou negácie satisfaktívnosti.

Výčitka ako slovné dohováranie, prejav rozhorčenia, nespokojnosti hovoriaceho býva implikovaná jeho záujmom o nápravu konania, správania sa adresáta. Výčitka je axiologická reakcia evokovaná pocitmi sklamania, rozčarovania, nespravodlivosti a nesplnenia očakávaní, je dôsledkom rozporu medzi očakávaním a konaním. Výčitke predchádza skutočnost', že adresát nevykonal to, čo sa od neho očakávalo, resp. vykonal niečo v rozpore s očakávaniami, pravidlami, normami, konvenciami. Výčitka je prejavom negatívneho postoja hovoriaceho $\mathrm{k}$ obsahu Q, ktorý sa spája s obsahom personálnosti: kým ja/my, kým ty/vy, kým on/ona/oni:

(111) Dúfam, že si si užil, kým ${ }^{4}$ ja som na teba otročila. 
(112) Celé dni som zavretá doma, kým ${ }^{4}$ ty si chodíš kade-tade!

(113) Nemôžeme stanovit’ pevný dátum svadby, kým ${ }^{l}$ nie sme zasnúbení.

Výčitka predpokladá verbálne dávat' do popredia fakty, udalosti, ktoré sú späté $\mathrm{s}$ hovoriacim a ktorým prisudzuje subjektívnu validitu. Realizuje sa $\mathrm{v}$ prítomnosti, čomu zodpovedajú prézentné tvary predikátov $\mathrm{v} \mathrm{P}$, zatial' čo $\mathrm{v} \mathrm{Q}$ je okrem prézentu možný préterit, ked’že $\mathrm{v} Q$ je postulovaný motív, zdroj výčitky. Otvára sa tak priestor pre kontrastívne posudzovanie faktov:

(114) Vidíš, sedíš tu ako zmoknuté kura, kým $m^{4}$ ja oslavujem, <..>.

Formula vidišs (vidite) má kontaktovú funkciu a hovoriaci ňou obracia pozornost' adresáta na komunikačnú situáciu. Častica ved' má význam akoby vysvetlenia časovej osi v $\mathrm{S}_{2}$ a $\mathrm{S}_{1}$, ktorá sa zavŕši do konca trvania deja $\mathrm{v} \mathrm{Q}$ :

(115) Ved' kým ${ }^{2}$ mi dôchodok priznáte, oberiete ma o všetku energiu, a ani sa ho nedožijem.

3.5 Komisívna KF vyjadruje sl'ub, ktorým sa hovoriaci zaväzuje niečo urobit', dat', dodržat' a pod. V pozadí je vzt'ah kooperácie, príslub ústretovosti, pochopenia hovoriaceho voči adresátovi. Forma budúceho času vyjadruje činnosti, stavy akoby $\mathrm{v}$ gnómickom poňatí. V P aj Q je sl’ub tematizovaný slovesným tvarom 1. osoby singuláru (plurálu) nedokonavého vidu, Q vyjadruje časovú ohraničenost' nadradenej vety:

(116) Budem ti pomáhat', kým ${ }^{I}$ budem vládat'.

(117) Budeme tu dotial', kým ${ }^{I}$ neprídu ostatní.

Sl’ub implikuje subjektívnu mieru optatívnosti, ktorú reflektuje možnost' postpozičného použitia častice len po spojke kým:

(118) Budem t'a milovat', kým ${ }^{l}$ len budem žit'.

Spojenie kým len má zdôrazňujúcu, gradientnú platnost' a vyjadruje vyšší stupeň predpokladov realizácie $\mathrm{P}$. K interakčným podmienkam slubu patrí aj to, že hovoriaci verí v úspešnú realizáciu činnosti.

3.6 Admonitívna KF je zacielená na adresáta. Varovanie je dôrazné upozornenie (na nebezpečenstvo), hrozba, výstražné napomínanie, vyhrážka, až zastrašovanie. Varovanie implikuje negatívne konzekvencie pre adresáta, jeho zámerom je predchádzat' možným negatívnym dôsledkom konania adresáta. Hovoriaci imperatívnym aj indikatívnym tvarom slovies v $\mathrm{P}$ vyjadruje zákaz, $v$ Q je špecifikované jeho časové trvanie:

(119) Počkáš si, kým ${ }^{l}$ ja zídem!

Varovanie má v Q slovesné tvary 1. osoby singuláru (plurálu) nedokonavého vidu, takže implikuje futúrum. 


\section{ZÁVER}

V článku sme sa zamerali na sémantické a komunikačno-pragmatické funkcie slovenskej spojky kým. Potvrdilo sa, že invariantnou sémantickou funkciou spojky kým je temporálna lokalizácia $\mathrm{P}$ na pozadí Q s predispozíciami na implicitnú alebo explicitnú kontrastívnost'. V slovenčine je pre súvetné propozície so spojkou kým ${ }^{l}$ typická limitatívna koincidencia $\mathrm{P}$ a Q, spojka kým$^{2}$ má význam sukcesívnej koincidencie, spojku kým ${ }^{3}$ charakterizuje simultánna koincidencia a súvetné propozície so spojkou kým $m^{4}$ sú vo vzt’ahu kontrastívnej simultánnej koincidencie. Spojka kým ${ }^{1}$ je temporálne limitujúca, spojky kým $m^{2}, k y m^{3}$ a $k y ́ m^{4}$ sú temporálne orientujúce. Z pohladu aktuálneho členenia výpovedí prototypickým vetosledom spojky $k^{\prime} m^{l}$ je tematicko-rematická postupnost', ktorá zodpovedá modelu $\mathrm{P}$, kým $^{l} \mathrm{Q}$; spojky kým², $k y ́ m^{3}$ majú častejšie vetosled $K y ́ m^{2 / 3} \mathrm{Q}, \mathrm{P}$, v ktorom sú situácie $\mathrm{S}_{2}$ sémanticky decentralizované. Spojka kým má vol'ný vetosled, ked’že odráža konfrontačnú perspektívu, ktorá je plne v kompetencii hovoriaceho.

Komunikačne sa najviac presadzuje spojka $\mathrm{kým}^{l}$, ktorá $\mathrm{v}$ kognitívnej mape (sieti) hovoriacich má pozíciu akoby centra perspektívy a prezentuje model „zdôvodňujúci“" ukončenie časovej platnosti nadradenej vety. V slovenčine je pre spojku kým ${ }^{l}$ príznačné obsadenie do P slovesa trvat'. V slovenčine aj ruštine sa v súvislosti so spojkou kým ${ }^{l}$ uplatňuje „mentálny litotes“, t. j. popretie opozita, ktorý sa realizuje ako expletívna negácia predikátu $\mathrm{v}$ Q. Z doterajších pozorovaní expletívnej negácie vyplýva, že predikáty v P môžu byt' v dokonavom aj nedokonavom vide, ale musia mat' sémantický príznak 'kontrolovatelnosti'. Pre obsah P totiž platí, že dej, činnost', proces, stav je posudzovaný z hladiska jeho limitatívnosti, t. j. fixuje temporálne neurčitú duratívnost's orientáciou na ukončenie situácie $S_{1}$. Slovesá v Q sú vždy v dokonavom vide, a ked’že spojenie perfektíva s negáciou fixuje orientáciu akoby na začiatok, nástup udalosti, negovaný výraz v Q kompenzuje neurčitost' duratívnosti $\mathrm{v}$ P. Spojka $k$ kým $^{l}$ je tiež v najmenšom konflikte systematizácií s inými synonymickými spojkami. Nazdávame sa, že nižšia častost' spojok kým $m^{2}, k y m^{3}$ a aj kým $m^{4}$ vyplýva z evidentne konkurenčných vzt’ahov k iným spojkám (operátorom). Ukázalo sa, že na komunikačno-pragmatickú realizáciu spojky kým má vplyv výber perspektívy, a to z aspektu objektivizácie (modus, tempus, aspekt), subjektivizácie (postoj emocionálny, evaluačný, preferenčný, epistemický) a vetosledu. Pragmatické pozadie má ponímanie časového intervalu v P a Q ako subjektívne krátky alebo dlhý interval; ako určitý alebo bližšie nešpecifikovaný (o čom svedčí otvorenost' pre adherentné používanie temporálnych a pragmatických kolokátov).

Spojenie temporálnosti a kontrastívnosti (s rôznou mierou prevahy jednej alebo druhej zložky) vytvára predpoklady na uplatňovanie spojky kým $\mathrm{v}$ asertívnej, direktívnej, interogatívnej, (ne)satisfaktívnej, komisívnej a admonitívnej komunikačnej funkcii. Ukázalo sa, že prevahu vykazujú súvetia obsahovo motivané negatívnymi 
životnými skúsenost’ami hovoriaceho. Negatívna tonalita sprevádza ilokúcie varovania, výčitky, námietky, upozornenia, odporúčania, príkazu, obáv; afirmatívnu tonalitu majú ilokučné funkcie návodu, návrhu, prosby a sl’ubu; ilokúcie konštatovania a odhodlania môžu byt' aj afirmatívne aj negatívne. Z pohl'adu komunikačných funkcií platí, že tvrdenie je síce primárnou komunikačnou funkciou výpovedí s časovým operátorom, ale spojka kým stavia do popredia aj iné ilokúcie, takže funguje v kontexte „upozadeného“ tvrdenia.

\section{Bibliografia}

BODNÁROVÁ, Martina: K problematike aspektu v kontexte pomerných (relatívnych) časov. In: Aspektuálnost' a modálnost' v slovenčine. Ed. Martina Ivanová. Prešov: Filozofická fakulta Prešovskej univerzity v Prešove 2009, s. $143-151$.

DANEŠ, František: Věta a text. Praha: Academia 1985. 234 s.

DOLNÍK, Juraj: Všeobecná jazykoveda. Opis a vysvetl'ovanie jazyka. Druhé, doplnené a upravené vydanie. Bratislava: VEDA, vydavatel'stvo Slovenskej akadémie vied 2013. $432 \mathrm{~s}$.

DOLNÍK, Juraj: Preferenčný aspekt rečových aktov. In: Jazykovedný časopis, 1995, roč. 46, s. 3 -11 .

Encyklopedický slovník češtiny. Ed. Petr Karlík - Marek Nekula - Jana Pleskalová. Praha: Nakladatelství Lidové noviny 2002. $604 \mathrm{~s}$.

FERENČÍKOVÁ, Adriana: Časové podrad’ovacie súvetie v slovenských nárečiach. Bratislava: VEDA, vydavatel'stvo Slovenskej akadémie vied 1986. $134 \mathrm{~s}$.

FILKORN, Vojtech: Povaha súčasnej vedy a jej metódy. Bratislava: VEDA, vydavatel'stvo Slovenskej akadémie vied 1998. $378 \mathrm{~s}$.

GREPL, Miroslav: Věty s významem nutnosti, možnosti (schopnosti) a záměru. In: Grepl, Miroslav - Karlík, Petr: Skladba češtiny. Olomouc: Votobia 1998a, s. 153 - 167.

GREPL, Miroslav: Komunikační (ilokuční) funkce výpovědi. In: Grepl, Miroslav - Karlík, Petr: Skladba češtiny. Olomouc: Votobia 1998b, s. 421 - 494.

HIRSCHOVÁ, Milada: Řečový akt, řečové jednání a komunikační funkce výpovědi. In: Slovo a slovesnost, roč. 65,2004 , s. $163-173$.

HIRSCHOVÁ, Milada: Pragmatika v češtině. Vyd. 2, dopl. Praha: Karolinum 2013. 336 s.

HIRSCHOVÁ, Milada: Slovesný vid a tzv. performativnost. In: Vidy jazyka a jazykovedy. Na počest' Miloslavy Sokolovej. Martin Ološtiak, Martina Ivanová, Daniela Slančová (eds.). Prešov: Prešovská univerzita v Prešove 2011, s. 155 - 161.

HORECKÝ, Ján: Ešte raz o spojke kým. In: Kultúra slova, 1997, roč. 31, č. 6, s. 326 - 329.

HORECKÝ, Ján - SOKOLOVÁ, Jana: Modelovanie v lingvistike. Nitra: Garmond 2003. 120 s.

IVANOVÁ, Martina: Modálne relátory. In: Morfologické aspekty súčasnej slovenčiny. Ed. Juraj Dolník. Bratislava: VEDA, vydavatel’stvo Slovenskej akadémie vied 2010, s. 218 - 264.

JAROŠOVÁ, Alexandra: Vidová opozícia a vidová korelácia v slovenčine. In: Jazykovedný časopis, roč. 64, 2013, s. 5 - 48 .

KAČALA, Ján: Syntaktický systém jazyka. Pezinok: Formát 1998. 144 s.

KESSELOVÁ, Jana a kol.: Spojky a spájacie prostriedky v slovenčine. Synchrónia - diachrónia - ontogenéza. Bratislava: VEDA, vydavatel'stvo Slovenskej akadémie vied 2013a. 312 s.

KESSELOVÁ, Jana: Spojky v komunikačných väzbách a kognitívnych súvislostiach (k vybraným aspektom zlučovacieho vzt’ahu). In: Jazykovedné štúdie XXX. Syntax a morfológia - väzby a súvislosti. Bratislava: VEDA, vydavatel'stvo Slovenskej akadémie vied 2013b, s. $101-112$. 
KESSELOVÁ, Jana: Operátory na rozširovanie a rozvíjanie výpovede. In: Morfologické aspekty súčasnej slovenčiny. Ed. Juraj Dolník. Bratislava: VEDA, vydavatel’stvo Slovenskej akadémie vied 2010, s. $326-386$.

Krátky slovník slovenského jazyka. Hlav. red. Ján Kačala, Mária Pisárčiková. Štvrté, doplnené a upravené vydanie. Bratislava: VEDA 2003.

Mluvnice češtiny 3. Skladba. Red. F. Daneš - M. Grepl - Z. Hlavsa. Praha: Academia 1987. 748 s.

ONDREJOVIČ, Slavomír: Medzi slovesom a vetou. Problémy slovenskej konverzie. Bratislava:

VEDA, vydavatel'stvo Slovenskej akadémie vied, 1989. $128 \mathrm{~s}$.

ORAVEC, Ján: Spojka kým. In: Kultúra slova, 1971, roč. 5, s. 3 - 8.

PAULINY, Eugen: Slovenská gramatika. (Opis jazykového systému). Bratislava: Slovenské pedagogické nakladatel'stvo 1981. $324 \mathrm{~s}$.

Slovenský národný korpus - verzia prim-6.1.20-public-vyv. Bratislava: Jazykovedný ústav L. Štúra SAV v Bratislave 2015. Dostupný na www: https://bonito.korpus.sk

Slovník súčasného slovenského jazyka. A - G. 1. vyd. Red. K. Buzássyová - A. Jarošová. Bratislava: VEDA 2006.

Slovník súčasného slovenského jazyka. H - L. Red. K. Buzássyová - A. Jarošová. Bratislava: VEDA 2011.

SOKOLOVÁ, Jana: O definičných vlastnostiach (verbálneho) textu. In: Slavica Nitriensia, 2012, roč. 1, s. $41-54$.

SOKOLOVÁ, Miloslava - ŽIGO, Pavol: Verbálne kategórie aspekt a tempus v slovenčine. Bratislava: VEDA, vydavatel'stvo Slovenskej akadémie vied 2014. 320 s.

ŽIGO, Pavol: Kategória času. In: Morfologické aspekty súčasnej slovenčiny. Ed. Juraj Dolník. Bratislava: VEDA, vydavatel'stvo Slovenskej akadémie vied 2010, s. $167-217$.

ŽIGO, Pavol: Kategória času v slovenskom jazyku. Bratislava: Univerzita Komenského 1997. $115 \mathrm{~s}$.

АПРЕСЯН, Юрий Дереникович: Фундаментальная классификация предикатов и системная лексикография. Dostupné na: iling.spb.ru/typo/materials/.../apresjan_spb2003.pdf [30.03.2015]

БОНДАРКО, Александр Владимирович: Полевые структуры в системе функциональной грамматики. In: Проблемы функциональной грамматики. Полевые структуры. Санкт-Петербург: Наука 2005, с. $12-28$.

БОРЩЕВ, Владимир Борисович - Парти, Барбара: Бытийные и локативные предложения что их различает? Тема-рематическая структура или диатеза? In: Динамические модели. Слово. Предложение. Текст. Сборник статей в честь Е. В. Падучевой. Москва: Языки славянских культур 2008, c. $137-153$.

БУЛЫГИНА, Татьяна Вячеславовна: К построению типологии предикатов в русском языке. In: Семантические типы предикатов. Отв. ред. О. Н. Селиверстова. Москва: Наука 1982, с. 7 - 83.

ИОРДАНСКАЯ, Лидия Николаевна: Семантика русского союза раз (в сравнении с некоторыми другими русскими союзами. In: Russian Linguistics 1988, vol. 12, p. 239 - 267.

ПАДУЧЕВА, Елена Викторовна: Эксплетивное отрицание и семантика союза ПОКА. In: Язык. Константы. Переменные. Памяти Александра Евгеньевича Кибрика. Санкт-Петербург: Алетейя 2014, с. $339-350$.

ПАДУЧЕВА, Елена Викторовна: Лексическая аспектуальнось и классификация предикатов по Маслову - Вендлеру. In: Вопросы языкознания, 58, 2009, № 6, с. 3 - 20.

ПАДУЧЕВА, Елена Викторовна: Семантические исследования. Семантика времени и вида в русском языке. Семантика нарратива. Москва: Языки русской культуры 1996. 464 с.

ПАДУЧЕВА, Елена Викторовна: Семантика вида и точка отсчёта. In: Известия АН СССР 1986, т. 55, № 5 , с. 413 - 424. 
ПАДУЧЕВА, Елена Викторовна: Высказывание и его соотнесённость с действительностью. (Референциальные аспекты семантики местоимений). Москва: Наука 1985. 272 с.

УРЫСОН, Елена Владимировна: Синтаксические свойства союзов и теория валентностей. In: Динамические модели. Слово Предложение Текст. Сборник статей в честь Е. В. Падучевой. Москва: Языки славянских культур 2008, с. 809 - 824.

УРЫСОН, Елена Владимировна: Союз ЕСЛИ и семантические примитивы. In: Вопросы языкознания, 50, 2001, № 4, с. $45-65$.

ФЁДОРОВА, Ольга Викторовна: Перед или после: что проще? (понимание сложноподчиненных предложений с придаточными времени). In: Вопросы языкознания, 54, 2005, № 6, с. 44 - 58.

ХРАКОВСКИЙ, Виктор Самуилович: Таксис следования в современном русском языке. In: Проблемы функциональной грамматики. Полевые структуры. Отв. ред. А. В. Бондарко. СанктПетербург: Наука, 2005, с. 29 - 85. 